Anthony M.H. Ho M SC PENG MD, Ian M. Fraser MD FRCPC, David D. Suria PHD FACB

\title{
Delayed digoxin toxicity following dis- continuance in acute renal failure
}

\begin{abstract}
A digitalized 75-year-old patient with postoperative renal failure demonstrated a progressive rise in serum digoxin concentration. peaking at $3.4 \mathrm{nmol} \cdot \mathrm{L}^{-1}$ three days following discontinuance of the drig. This was accompanied by cardiac bradyarrhythmias. Although the serum digoxin concentration had already started to climb from a therapeutic level prior to the discontinuance of the drug, the unabated and substantial rise was consistent with a dramasic decrease in the apparent volume of distribution of digoxin accompanying acute renal failure. Serum digoxin levels were determined with fluorescence polarization immunoassay, which has an improved specificity when compared to the commoniy used radioimmunoassays for digoxin.
\end{abstract}

Digoxin is cleared from the body primarily through glomerular filtration and partially through active renal tubular secretion. 'Following discontinuance of digoxin administration, the serum digoxin concentration (SDC) may be expected to decline at a rate which closely correlates with creatinine clearance. This assumes that all other factors influencing the SDC are constant. A patient is reported in acute renal failure whose serial SDC measurements rose after digoxin was stopped, peaking on the third day with a concentration of $3.4 \mathrm{nmol} \cdot \mathrm{L}^{-1}$. The pathogenesis of the SDC rise, which was accompanied by cardiac arrhythmias consistent with digoxin toxicity, will be discussed.

\section{Key words}

COMPLICATIONS: digitalis toxicity; KIDNEY: acute renal failure.

From the Department of Anaesthesia, McMaster University School of Medicine, Hamilton, Ontario, and the Departments of Medicine and Clinical Biochemistry, The Wellesley Hospital and The University of Toronto Faculty of Medicine, Toronto, Ontario.

Address correspondence to: Dr. Ian M. Fraser, Rm. 246, E.K. Janes Building, The Wellesley Hospital, 160 Wellesley Street E., Toronto, Ontario, Canada M4Y $1 \mathrm{~J} 6$.

\section{Case report}

An obese 75-year-old woman with type II diabetes mellitus, chronic arterial hypertension and coronary artery disease was admitted with an acute anterior myocardial infarction and small bowel ischaemia. On the day of admission (day (0), her medications included furosemide, potassium chloride, digoxin, and sublingual nitroglycerin. Under general anaesthesia, a laparotomy, superior mesenteric artery thrombectomy, and an aorto-superior mesenteric arterial bypass graft were performed. Her aorta was clamped for $60 \mathrm{~min}$ and a transient hypotensive episode to $95 \mathrm{mmHg}$ (systolic) occurred when the clamp was released (preoperative systolic pressure was $175 \mathrm{mmHg}$ ). The following day she underwent a "second look" laparotomy with resection of $0.75 \mathrm{~m}$ of jejunum and ileum. Following this operation, she developed congestive heart failure, supraventricular tachycardias, bronchospasm, and fever. Her medication regimen, until the 11 th day following admission, included digoxin, verapamil ( $5 \mathrm{mg}$ on days 3 and 6), furosemide, ethacrynic acid, potassium chloride, nifedipine (total dose $120 \mathrm{mg}$ over three days, ending on day 11), dopamine, dobutamine, aminophylline, netilmicin, cefoxitin, metronidazole, cimetidine, low dose subcutaneous heparin, and insulin with parenteral nutrition. On day 8 , the patient suffered a myocardial infarction, with a minimal elevation of the cardiac enzymes. On day 11 she developed respiratory failure and arterial hypotension. This episode was accompanied by a rapidly rising serum creatinine. The Figure illus: trates serial measurements of serum creatinine and digoxin, and the digoxin administration schedule. The last dose of digoxin was given on day 12 and the serum digoxin concentration (SDC) and creatinine clearance on day 13 were respectively $2.8 \mathrm{nmol} \cdot \mathrm{L}^{-1}$ and $0.16 \mathrm{ml} \cdot \mathrm{sec}^{-1}$ (reference range 1.0 to $2.5 \mathrm{nmal} \cdot \mathrm{L}^{-1}$ and 1.24 to $2.08 \mathrm{ml} \cdot \mathrm{sec}^{-1}$ respectively).

On day 14 the patient's cardiac thythm changed from sinus tachycardia to sinus bradycardia with episodes of junctional rhythm. The next day it deteriorated to episodes of sinus bradycardia with complete loss of AV transmission and transient loss of junctional escape. The 


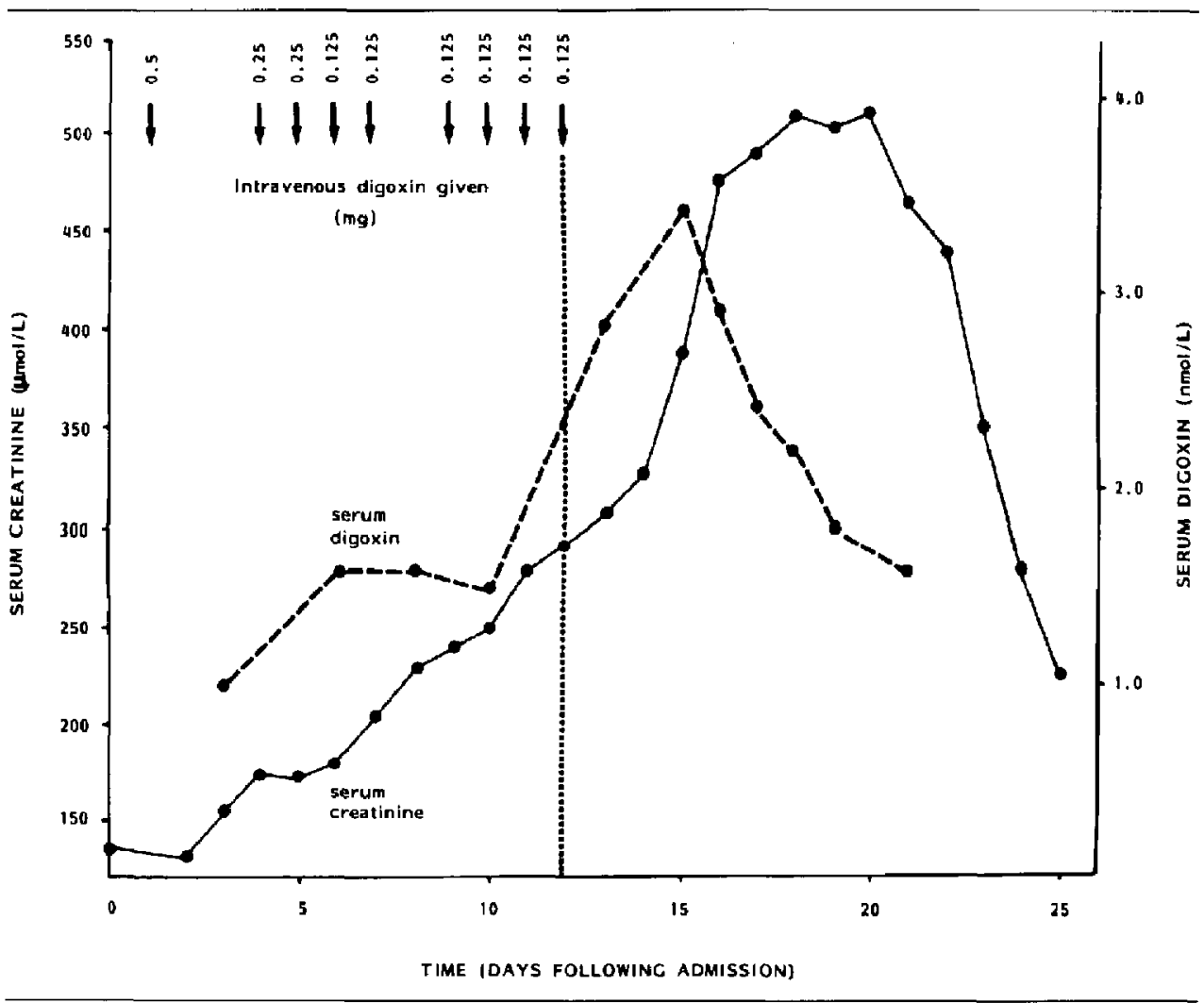

FIGURE Digoxin administration, serum digoxin and serum crcatinine during hospital stay.

latter episode reverted to an escape junctional rhythm during positioning of the patient prior to initiation of manual chest compressions. On that day the SDC was $3.4 \mathrm{nmol}-\mathrm{L}^{-1}$. With the exception of the promptly treated hypercarbic respiratory failure on day 11 , her blood $\mathrm{pH}$, bicarbonate, sodium, potassium, albumin, arterial oxygen saturation, and haemoglobin remained constant. As a result of parenteral supplementation, the total serum calcium rose to $2.5 \mathrm{nmol} \cdot \mathrm{L}^{-1}$ (serum albumin $25 \mathrm{~g} \cdot \mathrm{L}^{-1}$ ) on days 14 and 15 . On day 13 , the serum magnesium level peaked at $1.5 \mathrm{nmol} \cdot \mathrm{L}^{-1}$. During the next two wecks the daily urine output ranged between 1-3L with the patient's body weight remaining constant (i.e., $+1-5$ per cent). As illustrated in the Figure, there was a gradual decline in the serum digoxin concentration and improvement in renal function. which was accompanied by a return to normal sinus rhythm.

\section{Discussion}

In the equilibrium state, serum digoxin concentration is determined by a balance between the administration and elimination of the drug in a conceptually constant dilutional volume within the body. ${ }^{1}$ Abnormalities of renal function can decrease the elimination of the drug from the body. This can be conveniently expressed as the half life $\left(t_{t} \beta\right)$, which (for intravenous administration) lengthens from a normal of 33.6-44.4 hours to between 84-148 hours in advanced renal failure. ${ }^{2}$ When digoxin therapy is terminated, it is generally assumed that SDC will decrease over time, with the $t_{1} \beta$ dependent on the rate of digoxin elimination. Deviation from this assumption in our case probably resulted from the rapid decrease in the apparent volume of distribution (VD) of digoxin as renal failure set in.

Three similar cases have been reported. A 56-year-old 
man with acute renal failure demonstrated an unanticipated twofold rise in SDC during the nine days after the last administered dose of the drug, peaking at $6.9 \mathrm{nmol} \cdot \mathrm{L}^{-1} .^{3}$ The second report involved a 75-year-old man with multiple trauma, resulting in acute hepatic and renal failure. ${ }^{4}$ Following $1 \mathrm{mg}$ of digoxin in two divided doses, the SDC rose above the therapeutic range over the next ten days, with a peak of $3.1 \mathrm{nmol} \cdot \mathrm{L}^{-1}$ occurring on the tenth day after the last dose. The thind report described a 73-year-old man with acute renal failure who was given a total of $1 \mathrm{mg}$ of digoxin IV over three days. The SDC peakcd at $5.5 \mathrm{nmol} \cdot \mathrm{L}^{-1} 11$ days later. ${ }^{5}$

In all three cases, radioimmunoassay (RIA) was used for quantitating SDC. With RIA, digoxin in a patient's serum is allowed to compete with a known amount of radioactive digoxin for the binding sites on anti-digoxin antibody. The antibody-bound digoxin is then separated and its radioactivity compared to a set of standards. Unfortunately, this method detects digoxin-like immunoreactive substance in the sera of uraemic patients, giving falsely elevated, or false positive SDCs. ${ }^{6}$

Our digoxin analysis was based on the Abbott TDx system which utilizes the fluorescence polarization immunoassay (FPIA) technique ${ }^{7}$ and involves the competitive binding of antibody between Huorescence-labelled digoxin and unlabelled digoxin from patient serum. Unlike the RIA technique, this analysis is preceded by deproteinization with trichloracetic acid, which eliminates retained middle molecules and any elevated glycoprotein or glycosylated protein associated with uraemia, ${ }^{8}$ as well as the endogenous digoxin-like immunoreactive factor, which is tightly but reversibly bound to the serum proteins. ${ }^{9}$ Thus, the problem of detecting a falsely elevated or false positive SDC by RIA in uraemic patients is largely overcome by the use of FPIA. Using the latter technique, Heazlewood $e t$ al. ${ }^{8}$ found no detectable digoxinlike material in 60 patients with acute or chronic renal failure. None had received digitalis. The higher specificity of FPIA is also supported in a study of 25 uraemic patients by Yatscoff et $a l^{10}$ who found the degree of interference by digoxin-like immunoreactive substances to be generally less than that seen in commonly used RIAs for digoxin.

The apparent rise of SDC in ous patient could have been caused by a number of factors. The use of FPIA virtually eliminates any significant interference by proteinbound digoxin-like immunoreactive substance. It is also unlikely that the cross-reaction of digoxin metabolites with antibody to digoxin could have accounted for the rise in SDC, since it has been found that 90 and 94 per cent of the administered $3 \mathrm{H}$-digoxin radioactivity in serum and urine respectively were chromatographed and detected as digoxin. ${ }^{5}$ A catabolic state could produce an accelerated breakdown of muscles and other body tissues with concomitant release of cellular bound digoxin and its metabolites. Delayed absorption of "third space" fluid containing digoxin, associated with repeated abdominal surgery and poor circulation could add digoxin to the circulating serum pool. A verapamil-digoxin interaction could elevate the SDC. ${ }^{11}$ However, it is unlikely that the two doses of verapamil given on days 3 and 6 would have contributed to this phenomenon. We believe that the most likely mechanism for the increased SDC was the alteration in VD secondary to as yet uncharacterized uraemic substances which displace tissue bound digoxin into the circulation. ${ }^{3}$

In normal renal function the VD is about $570 \mathrm{~L}$ $\left(9 \mathrm{~L} \cdot \mathrm{kg}^{-1}\right)$, whereas in renal failure, based on RIA measurements, it can decrease to as low as $83 \mathrm{~L}\left(1.5 \mathrm{~L} \cdot \mathrm{kg}^{-1}\right) .^{12}$ Based on steady-state serum radioactivity after the injection of $3 \mathrm{H}$-digoxin, a VD of 140 litres has been reported in a patient with renal failure. ${ }^{5}$ In comparison to the previously reported cases, the less severc nature of our patient's renal impairment, and possibly the use of FPIA, could have limited the magnitude and duration of the rise in SDC. Digoxin associated rhythm disturbances are diagnosed on the basis of compatible arrhythmias and the exclusion of other obvious causes. An elevated SDC is contributory, but not definitive. ${ }^{13}$ In the context of multiorgan system dysfunction, including two recent myocardial infarctions, she was predisposed to digoxin induced arrhythmias and we believe the temporal relationship of the peak SDC strongly suggests causality.

In conclusion, the transition from normal to abnornal renal function can be accompanied by a significant reduction in the VD of digoxin. When this is coupled with the obvious impairment of excretion of this drug, a rise in SDC levels accompanied by digoxin toxicity can be expected in susceptible patients. Clinicians should be aware of the possibility of a persistent rise in SDC levels after halting drug administration in patients with acute renal failure and the necessity of using assay methods uninfluenced by uraemia.

\section{Acknowledgements}

The authors gratefully acknowledge the review of the manuscript by Dr. Geoffrey L. Dunn, the secretarial assistance of Ms. J. MacInnis and Mrs. Barbara Roszel, and the support of the Nelson A. Hyland Foundation and the Ewart R. Angus Foundation. Thanks are also extended to Dr. Paul Rolan of The University of Adelaide, Australia, for kindly providing the authors with details of the patient described in reference 4 . 


\section{References}

1 Reuning RH, Sams RA, Notari RE. Role of pharmacokinetics in drug cosage adjustment. 1. Pharmacologic effect kinetics and apparent volume of distribution of digoxin. J Clin Pharmacol 1973; 13: 127-41.

2 Gault MH, Sugden D, Maloney C, Ahmed M. Tweeddale $M$. Biotransformation and clinination of digoxin with normal and minimal renal function. Clin Pharmacol Ther 1979; 25: 499-513.

3 Craver $J L$, Valdes $R J r$. Anomalous serum digoxin concentrations in uremia. Ann Intern Med 1983; 98: 483-4.

4 Rolan PE, Frewin DB, Hagley SR. Anomalous serum concentrations of digoxin. Ann Intern Med 1983; 99: 280.

5 Gault MH, Gallway B, Fine A, Vasdev S. Rising serum digoxin without further dosage in acute renal failure. Nephron 1984; 37: 190-4.

6 Graves $S W, B r o w n B$, Valdes $R J r$. An endogenous digoxinlike substance in patients with renal impairment. Ann Intern Med 1983; 99: 604-8.

7 Ferreri LF, Raisys VA, Opheim KE. Analysis of digoxin concentrations in scrum by fluorescence polarization immunoassay: an evaluation. $J$ Anal Tox 1984; 8: $138-40$.

8 Heazlewood VJ, Heazlewood RL, Jellett LB. An endogenous digoxin-like substance and renal failure. Ann Intern Med 1984; 100: 618

9 Valdes $R J r$. Endogenous digoxin-like immunoreactive factors: impact on digoxin measurements and potential physiological implications. Clin Chem 1985; 31: 1525-32.

10 Vatscoff $K W$. Desjardins PRE, Dalton JG. Digoxin-like immunoreactivity in the serum of neonates and uremic patients, as measured in the Abbott TDx. Clin Chem 1984: 4: 588 .

11 Klein HO, Lang R, DiSegni E, Kaplinsky E. Verapamildigoxin interaction. N Eng! J Med 1985; 303: 160.

12 Gault MH. Churchill DN. Kalra J. Loading dose of digoxin in renal failure. Br J Clin Pharmacol 1980; 9: 593-7.

13 Smith TW. Pharmacokinetics, bioavailablity and serum levels of cardiac glycosides. J Am Coll Cardiol 1985; 5(Suppl) 10: 43A-50A.
Résumé

Un patient de 75 ans digitalisé atteint d'une insuffisance rénale post-operatoire a démontré une augmentation progressive de sa digoxinémie jusqu' à $3.4 \mathrm{mmol} \cdot L^{-1}$ trois jours après l'arrêt du médicament. Cette augmentation de la digoxinémie ful accompagnée par des bradyarythmies. Même si la digoxinémie avait déjà commencé à augmenter avant l'arrêt du médicament cette augmentation substantielle et constante était due d̀ une diminution dramatique du volume apparent de distribution de la digoxine après l'insuffisance rénale. La digoxinémie était déterminée par une mérhode qui arnéliore la spécificité comparativement à la méthode habituelie. 